\title{
Evaluation of cellulolytic activity in insect digestive fluids
}

\author{
L.-J. Su ${ }^{1 *}$, H.-F. Zhang ${ }^{1 *}$, X.-M. Yin ${ }^{2 *}$, M. Chen ${ }^{1}$, F.-Q. Wang ${ }^{1}$, H. Xie ${ }^{1}$, \\ G.-Z. Zhang ${ }^{1}$ and A.-D. Song ${ }^{1}$ \\ ${ }^{1}$ College of Life Sciences, Henan Agricultural University, Zhengzhou, \\ Henan, China \\ ${ }^{2}$ College of Plant Protection, Henan Agricultural University, \\ Zhengzhou, Henan, P.R. China \\ *These authors contributed equally to this study. \\ Corresponding author: A.-D. Song \\ E-mail: sulijuan816@126.com
}

Genet. Mol. Res. 12 (3): 2432-2441 (2013)

Received March 27, 2012

Accepted August 3, 2012

Published January 4, 2013

DOI http://dx.doi.org/10.4238/2013.January.4.11

\begin{abstract}
Efficient and low-cost cellulolytic enzymes are urgently needed to degrade recalcitrant plant biomass during the industrial production of lignocellulosic biofuels. Here, the cellulolytic activities in the gut fluids of 54 insect species that belong to 7 different taxonomic orders were determined using 2 different substrates, carboxymethyl cellulose (CMC) (approximating endo$\beta-1,4$-glucanase) and filter paper (FP) (total cellulolytic activities). The use of $\mathrm{CMC}$ as the substrate in the zymogram analysis resulted in the detection of distinct cellulolytic protein bands. The cellulolytic activities in the digestive system of all the collected samples were detected using cellulolytic activity analysis. The highest CMC gut fluid activities were found in Coleoptera and Orthoptera, while FP analysis indicated that higher gut fluid activities were found in several species of Coleoptera and Lepidoptera. In most cases, gut fluid activities were higher with CMC than with FP substrate, except for individual Lepidoptera species. Our data indicate that the
\end{abstract}


origin of cellulolytic enzymes probably reflects the phylogenetic relationship and feeding strategies of different insects.

Key words: Cellulolytic activity; Insect; Digestive fluids; Lignocellulosic biofuels; Cellulase zymography

\section{INTRODUCTION}

Because of the increasing demand to overcome energy shortages and achieve stable economic development, lignocellulose-based biofuels have recently become a major focus of industrial and academic communities worldwide (Sun and Scharf, 2010). During biofuel production, linear chains of cellulose, which consist of glucose residues connected by a $\beta-1,4$ linkage, need to be degraded to glucose, which is then fermented to produce ethanol. At present, even though microbial and chemical degradation of cellulose has been widely used, the use of combined cellulolytic enzymes remains limited because of the high cost of biotechnological tools (Wyman, 1999). Furthermore, in industry, breakthrough technologies to overcome the barriers of developing cost-effective processes for converting biomass to fuels and chemicals have yet to be fully realized. Therefore, there is an urgent need to discover and develop more efficient cellulolytic enzymes that reduce biofuel production cost, in addition to having applications in other industrial processes (Wyman, 2007).

In general, cellulolytic activities were originally thought to be limited to plants, bacteria, and fungi. With increased study of cellulolytic activities, increasing evidence has shown that cellulases are also present in the animal kingdom, particularly in insects (Yokoe and Yasumasu, 1964; Watanabe and Tokuda, 2001; Lo et al., 2003), including more than 20 insect families that represent 10 distinct insect orders, such as Thysanura, Plecoptera, Dictyoptera, Orthoptera, Isoptera, Coleoptera, Trichoptera, Hymenoptera, Phasmida, and Diptera (Sun and Scharf, 2010). These insect cellulases may degrade lignocellulosic biomass easily and efficiently and might serve as highly efficient natural bioreactors. The types of biomass substrates fed on by cellulolytic insects are diverse, ranging from substrates of agricultural crops (Poaceae, Solanaceae) to woody forests (Salicaceae, Anacardiaceae, Moraceae, etc.). Therefore, recent studies have focused on the ability of these insects to feed on wood, foliage, and detritus, understand how these insects digest food, such as structural and recalcitrant lignocellulose, and their potential to enhance current biofuel technologies and processing.

Insects present attractive and potential candidates for highly efficient natural bioreactors, from which novel cellulolytic enzymes are being sought. The number of novel cellulases and hemicellulases, as well as associated encoding genes, from a variety of cellulose-feeding insects has been continuously updated in recent years. Examples include Apriona germari (Jing et al., 1996), Dendroctonus armandi (Wang et al., 2007; Wang and Chen, 2008), Eucryptorrhynchus chinenis (Yong et al., 2007), and Periplaneta americana, for which high carboxymethyl cellulase (CMCase) and filter paper cellulase (FP)ase activities have been measured, amounting to 0.89 and $0.12 \mathrm{U} / \mathrm{mL}$, respectively (Gijzen et al., 1994). Furthermore, another study detected 3 active protein bands for carboxymethyl cellulose (CMC) in Anoplophora glabripennis by using zymogram analysis (Geib et al., 2010).

Although relevant studies on cellulolytic activity in insects are available (Watanabe and Tokuda, 2001), the quantitative characterization of cellulolytic activities in a 
broad number of insect species remains very limited (Cazemier et al., 1997; Oppert et al., 2010). Furthermore, studies on insect cellulolytic activities by using FP as a substrate have not been performed until the current study. In the present study, we collected 54 phytophagous insect species that belong to 7 orders, including Diptera, Orthoptera, Coleoptera, Hymenoptera, Lepidoptera, Dictyoptera, and Dermaptera. We evaluated the relative cellulolytic activities of gut fluids from all 54 insect species by using soluble CMC and FP cellulose as substrates.

\section{MATERIAL AND METHODS}

\section{Insect collection and dissection}

Experimental insects (including adults and larvae) were collected from a field in Henan Province, except for Lasioderma serricorne, which was obtained from laboratory cultures at the Zoology Laboratory of Henan Agricultural University. The life stages, collection site, and plant host tissues for each species are listed in Table 1. As soon as possible after collection, the insect intestines were dissected on ice for subsequent assays. The dissected tissues were cut into small pieces, homogenized with liquid nitrogen, dissolved in phosphate-buffered saline (PBS) at $100 \mathrm{mg}$ tissues/mL PBS buffer, vortex-mixed, and centrifuged at 12,000 $\mathrm{g}$ for $5 \mathrm{~min}$ at $4^{\circ} \mathrm{C}$. Supernatants were used as crude cellulase samples, transferred to new centrifuge tubes, and stored at $-80^{\circ} \mathrm{C}$ until use (Oppert et al., 2010).

\section{Determination of cellulolytic activity}

Protein concentrations of gut fluid samples were quantified using the Coomassie Protein Assay Reagent (Pierce, Rock-ford, IL, USA), with bovine serum albumin as the standard. Two cellulose substrates with distinct properties were used in the cellulase assays: CMC sodium salt (Sigma-Aldrich, USA) and FP (hai Tang strainer filters, China). CMCase and FPase activities were determined by measuring the amount of reducing sugars released from CMC and FP with a modified 3,5-dinitrosalicylic acid assay (Miller, 1959).

Cellulolytic assays with CMC and FP were performed using 10-50 $\mu \mathrm{g}$ proteins from each insect fluid sample. Protein samples were mixed with either $1.5 \% \mathrm{CMC}$ sodium salt or FP $(2 \times 3 \mathrm{~cm})$ suspended in $100 \mathrm{mM}$ sodium citrate buffer, $\mathrm{pH} 4.8$, and were then incubated for $0.5 \mathrm{~h}(\mathrm{CMC})$ or $1 \mathrm{~h}(\mathrm{FP})$ at $50^{\circ} \mathrm{C}$. To stop enzymatic activity, a modified 3,5-dinitrosalicylic acid reagent containing Rochelle salt (Miller, 1959) was added to the samples. Then, color was developed at $100^{\circ} \mathrm{C}$ for $15 \mathrm{~min}$. The microplates were cooled at room temperature for at least 5 min and then centrifuged at $2000 \mathrm{~g}$ for 2 min to remove any remaining substrate. Supernatants were then transferred to polystyrene microplates, and absorbance at $550 \mathrm{~nm}$ was determined using a TU-1901 spectrophotometer (Jingke, China). Background amounts of reducing sugars were corrected by subtracting ultimate values from initial values of the calculated reducing sugars in the sample. One unit of enzymatic activity was defined as the amount of enzyme released from $1 \mu \mathrm{mol}$ of reducing sugar (glucose equivalents) per minute at $50^{\circ} \mathrm{C}$ and $\mathrm{pH} 4.8$. Specific activities were reported as unit per microgram of proteins. In all experiments, cellulase activities were determined by at least 3 independently replicated experiments, and the mean values were calculated (Willis et al., 2010). 
Table 1. Taxonomies, developed stages, and dietary of insect species collected for enzyme activity using carboxymethyl cellulose and filter paper substrates with digestive system contents extracted from insect gut.

\begin{tabular}{|c|c|c|c|c|c|}
\hline Number & $\begin{array}{l}\text { Order: Family: Genus species } \\
\text { (taxonomic authority) }\end{array}$ & $\begin{array}{l}\text { Life-stage } \\
\text { sampled }\end{array}$ & $\begin{array}{l}\text { Food resource(s) } \\
\text { (plant tissues) })^{\mathrm{b}}\end{array}$ & $\begin{array}{c}\text { No. of } \\
\text { individuals }\end{array}$ & $\begin{array}{l}\text { Collecting } \\
\text { locality }^{\mathrm{d}}\end{array}$ \\
\hline & \multicolumn{5}{|l|}{ Lepidoptera } \\
\hline & Pyralidae & & & & \\
\hline 1 & Diaphania quadrimaculalis & Larvae & Metaplexis japonica $(\mathrm{L})$ & 12 & ZFP \\
\hline 2 & Sylepta derogata & Larvae & & 8 & ZFP \\
\hline 3 & Glyphodes pyloalis & Larvae & Broussonetia papyrifera $(\mathrm{L})$ & 4 & ZFP \\
\hline 4 & Botyodes principalis & Larvae & Cotinus coggygria $(\mathrm{L})$ & 15 & ZZS \\
\hline 5 & Diaphania indica & Larvae & Pterocarya stenoptera $(\mathrm{L})$ & 5 & ZZS \\
\hline 6 & Locastra muscosalis & Larvae & Cotinus coggygria $(\mathrm{L})$ & 23 & YDM \\
\hline 7 & Omphisa plagialis Wileman & Larvae & Aesculus chinensis (L) & 5 & $\mathrm{ZZS}$ \\
\hline \multirow[t]{2}{*}{8} & Algedonia coclesalis & Larvae & Bambusoideae & 25 & $\mathrm{ZZS}$ \\
\hline & Sphingidae & & & & \\
\hline 9 & Clanis bilineata & Larvae & Ziziphus jujuba (L) & 5 & LXM \\
\hline 10 & Phyllosphingia dissimilis & Larvae & Platycarya strobilacea $(\mathrm{L})$ & 5 & YDM \\
\hline 11 & Smerinthus planus & Larvae & Prunus armeniaca (L) & 4 & YDM \\
\hline 12 & Psilogramma menephron & Larvae & Vitex negundo $(\mathrm{L})$ & 5 & YDM \\
\hline \multirow[t]{2}{*}{13} & Agrius convolvuli & Larvae & Ipomoea batatas (L) & & $\mathrm{ZZS}$ \\
\hline & Geometridae & & & & \\
\hline 14 & Culcula panterinaria & Larvae & Cotinus coggygria (L) & 5 & YDM \\
\hline 15 & Percnia giraffata & Larvae & Diospyros kaki (L) & 5 & YDM \\
\hline 16 & Ophthalmodes albosignaria & Larvae & Platycarya strobilacea $(\mathrm{L})$ & 4 & YDM \\
\hline 17 & Ophthalmitis irrorataria & Larvae & $\begin{array}{l}\text { Balsaminaceae } \\
\text { (I) }\end{array}$ & 10 & YDM \\
\hline \multirow[t]{2}{*}{18} & Buzura suppressaria & Larvae & Cotinus coggygria $(\mathrm{L})$ & 10 & YDM \\
\hline & Noctuidae & & & & \\
\hline \multirow{3}{*}{20} & Argyrogramma albostriata & Larvae & Abutilon theophrasti (L) & 11 & ZFP \\
\hline & $\begin{array}{l}\text { Chytonix segregata } \\
\text { Totricidae }\end{array}$ & Larvae & Humulus japonicus (L) & 5 & ZZS \\
\hline & $\begin{array}{l}\text { Tortricidae } \\
\text { Archips xylosteana }\end{array}$ & Larvae & Grewia biloba $(\mathrm{L})$ & 23 & ZFP \\
\hline \multirow{2}{*}{22} & Cryptophlebia ombrodelta & Larvae & $\begin{array}{l}\text { Pterocarva stenoptera }(\mathrm{L}) \\
\text { Pterion }\end{array}$ & 5 & ZZS \\
\hline & Limacodidae & & & & \\
\hline 23 & Cnidocampa flavescens & Larvae & Pterocarya stenoptera $(\mathrm{L})$ & 5 & ZZS \\
\hline \multirow[t]{2}{*}{24} & Parasa consocia & Larvae & Prunus armeniaca $(\mathrm{L})$ & 5 & YDM \\
\hline & Notodontidae & & & & \\
\hline 25 & Phalera flavescens & Larvae & Malus spectabilis (L) & 30 & ZZS \\
\hline 26 & $\begin{array}{l}\text { Uropyia meticulodina } \\
\text { Lymantridae }\end{array}$ & Larvae & Carya cathayensis $(\mathrm{L})$ & 5 & YDM \\
\hline \multirow{3}{*}{$\begin{array}{l}27 \\
28\end{array}$} & Porthesia piperita & Larvae & Glycine $\max (\mathrm{L})$ & 5 & ZZS \\
\hline & Stilpnotia salicis & Larvae & Populus tomentosa $(\mathrm{L})$ & 5 & $\mathrm{ZZS}$ \\
\hline & Saturniidae & & & & \\
\hline 29 & $\begin{array}{l}\text { Actias selene ningpoana } \\
\text { Cossidae }\end{array}$ & Larvae & Platycarya strobilacea $(\mathrm{L})$ & 5 & YDM \\
\hline \multirow{2}{*}{$\begin{array}{l}31 \\
32\end{array}$} & $\begin{array}{l}\text { Papillonidae } \\
\text { Sericinus montelus }\end{array}$ & Larvae & Aristolochia debilis $(\mathrm{L})$ & 11 & YDM \\
\hline & Papilio xuthus & Larvae & Zanthoxylum planispinum (L) & 5 & YDM \\
\hline \multirow[t]{2}{*}{33} & $\begin{array}{l}\text { Nymphalidae } \\
\text { Polygonia c-aureum Linnaeus } \\
\text { Coleoptera }\end{array}$ & Larvae & Humulus japonicus (L) & 5 & ZZS \\
\hline & Cerambycidae & & & & \\
\hline 34 & Megopis sinica & Larvae & Populus tomentosa $(\mathrm{W})$ & 5 & ZFP \\
\hline 35 & Trichoferus campestris & Larvae & Populus tomentosa (W) & 5 & ZZS \\
\hline 36 & Batocera horsfieldi Hope & Larvae & Salix babylonica $(\mathrm{W})$ & 5 & SQS \\
\hline \multirow[t]{2}{*}{37} & Massicus raddei Blessig & Larvae & Salix babylonica (W) & 5 & $\mathrm{SQS}$ \\
\hline & $\begin{array}{l}\text { Lucanidae } \\
\text { Dorcus titanus }\end{array}$ & & & & 7FP \\
\hline 38 & $\begin{array}{l}\text { Dorcus titanus } \\
\text { Tenebrionidae }\end{array}$ & Larvae & Populus alba (W) & 5 & ZFP \\
\hline 39 & Tenebrio obscurus Fabricius & Larvae & Salix babylonica $(\mathrm{W})$ & 5 & SQS \\
\hline \multirow[t]{2}{*}{40} & $\begin{array}{l}\text { Anobiidae } \\
\text { Lasioderma serricorne } \\
\text { Orthoptera }\end{array}$ & Larvae & Nicotiana tabacum (L) & 5 & ZZS \\
\hline & Acrididae & & & & \\
\hline \multirow{3}{*}{42} & Gonista bicolor & Adult & Poaceae $(\mathrm{L}, \mathrm{S})$ & 5 & ZZS \\
\hline & Acrida cinerea & Adult & Poaceae (L, S) & 5 & $\mathrm{ZZS}$ \\
\hline & $\begin{array}{l}\text { Catantopidae } \\
\text { Ewthorforiolinidifom }\end{array}$ & & & & \\
\hline 43 & Fruhstorferiola viridifemorata & Adult & Poaceae $(\mathrm{L}, \mathrm{S})$ & 5 & ZZS \\
\hline
\end{tabular}

Continued on next page 


\begin{tabular}{|c|c|c|c|c|c|}
\hline Number & $\begin{array}{l}\text { Order: Family: Genus species } \\
\text { (taxonomic authority) }\end{array}$ & $\begin{array}{l}\text { Life-stage } \\
\text { sampled }\end{array}$ & $\begin{array}{l}\text { Food resource }(\mathrm{s})^{\mathrm{a}} \\
\text { (plant tissues) }^{\mathrm{b}}\end{array}$ & $\begin{array}{l}\text { No. of } \\
\text { individuals }^{\mathrm{c}}\end{array}$ & $\begin{array}{l}\text { Collecting } \\
\text { locality }^{\mathrm{d}}\end{array}$ \\
\hline 44 & $\begin{array}{l}\text { Oxya hyla intricata } \\
\text { Oedipodidae }\end{array}$ & Adult & Poaceae (L, S) & 5 & ZZS \\
\hline 45 & $\begin{array}{l}\text { Gastrimargus marmoratus } \\
\text { Pyrgomorphidae }\end{array}$ & Adult & Poaceae $(\mathrm{L}, \mathrm{S})$ & 5 & YDM \\
\hline 46 & $\begin{array}{l}\text { Atractomorpha sinensis } \\
\text { Conocephalidae }\end{array}$ & Adult & Poaceae $(L, S)$ & 5 & ZZS \\
\hline 47 & $\begin{array}{l}\text { Conocephalus chinensis } \\
\text { Tettigoniidae }\end{array}$ & Adult & Poaceae $(L, S)$ & & ZZS \\
\hline 48 & $\begin{array}{l}\text { Atlanticus sinensis } \\
\text { Gryllidae }\end{array}$ & Adult & Poaceae (L, S) & 5 & YDM \\
\hline 49 & $\begin{array}{l}\text { Velarifictorus micado } \\
\text { Diptera } \\
\text { Tipulidae }\end{array}$ & Adult & Poaceae $(\mathrm{L}, \mathrm{S})$ & 5 & YDM \\
\hline 50 & $\begin{array}{l}\text { Nephrotoma sinensis } \\
\text { Syrphidae }\end{array}$ & Larvae & Populus alba $(\mathrm{W})$ & 5 & ZFP \\
\hline 51 & $\begin{array}{l}\text { Eristalomyia tenax } \\
\text { Hymenoptera } \\
\text { Argidae }\end{array}$ & Larvae & Populus alba (W) & 5 & ZFP \\
\hline 52 & $\begin{array}{l}\text { Arge pagana } \\
\text { Dermaptera } \\
\text { Labiduridae }\end{array}$ & Larvae & Cotinus coggygria $(\mathrm{L})$ & 5 & YDM \\
\hline 53 & $\begin{array}{l}\text { Labidura japonica } \\
\text { Blattaria }\end{array}$ & Adult & Omnivorous & 5 & ZFP \\
\hline 54 & $\begin{array}{l}\text { Eupolyphaga } \\
\text { Polyphaga plancyi }\end{array}$ & Adult & Omnivorous & 5 & ZFP \\
\hline
\end{tabular}

${ }^{\text {a} H o s t ~ p l a n t ~ s p e c i e s ~ f r o m ~ w h i c h ~ s a m p l e d ~ l a r v a e ~ a n d ~ a d u l t ~ w e r e ~ r e c o v e r e d . ~}{ }^{b}$ Plant tissues commonly consumed by sampled life-stage $(\mathrm{L}=$ leaves, $\mathrm{S}=$ stems, $\mathrm{W}=$ wood $) .{ }^{\mathrm{c}}$ Number of individuals for all biological replicates. ${ }^{\mathrm{d}}$ Locality where samples were collected $(\mathrm{ZFP}=$ Zhengzhou city forest park; ZZS = Zhengzhou city suburb; LXM = Luoyang city Xianglu mountain; YDM = Yuzhou city Dahongzhai mountain; SQS = Shangqiu city suburb).

\section{Cellulase zymography}

Cellulolytic activity bands were detected using the zymogram method used in a previous study (Oppert et al., 2010), with minor modifications. Ten percent sodium dodecyl sulfate-polyacrylamide gel electrophoresis (SDS-PAGE) gels were prepared by adding $0.1 \% \mathrm{CMC}(\mathrm{mg} / \mathrm{mL})$ before polymerization.

Commercial grade Aspergillus niger cellulase (MP Biomedicals, approximately 8 $\mu \mathrm{g}$ per lane) was used as a positive control. Gut extracts were thawed on ice and solubilized in 1 volume of sample buffer (50 mM Tris- $\mathrm{HCl}, \mathrm{pH}$ 6.8, $10 \%$ glycerol, $2 \%$ SDS, $1 \%$ $\beta$-mercaptoethanol, $0.01 \%$ bromophenol blue), followed by partial denaturation at $70^{\circ} \mathrm{C}$ for $20 \mathrm{~min}$ to decrease activity-band smearing due to continuous enzymatic activity during electrophoresis. Samples were briefly centrifuged to collect the evaporated solution after heating and were then loaded on the gels. Protein samples were run on $10 \%$ SDS-PAGE gels at 100 $\mathrm{V}$ (constant) and $4^{\circ} \mathrm{C}$ for approximately $4 \mathrm{~h}$, or until the dye reached the bottom of the gel.

After electrophoresis, the gels were first washed in $2.5 \%(\mathrm{w} / \mathrm{v})$ Triton X-100 for $1 \mathrm{~h}$, washed in $50 \mathrm{mM}$ acetate buffer, $\mathrm{pH} 5$, for $1 \mathrm{~h}$, and then incubated at $55^{\circ} \mathrm{C}$ for 30 $\mathrm{min}$ in the same buffer. After staining with $0.1 \%(\mathrm{w} / \mathrm{v})$ Congo red (Acros Organics) for 15 min, the gels were further washed with $1 \mathrm{M} \mathrm{NaCl}$ until the cellulase bands became visible. Finally, the gels were immersed in 5\% (v/v) acetic acid to improve band clarity. The gels were photographed, and the pictures were inverted and enhanced using the Adobe Photoshop CS2 software (v. 9.0.2) (Picart et al., 2007). 


\section{RESULTS}

\section{CMCase activity in gut fluids}

When using CMC as the substrate, cellulolytic activities were detected in the gut fluids of all 54 phytophagous or xylophagous insect species (Figure 1B). Gut fluid cellulolytic activities evaluated using the CMC substrate were generally higher in Coleoptera (Cerambycidae), Orthoptera, and Blattaria (Polyphaga plancyi) orders. In these 3 orders, the majority of cellulolytic activities exceeded $0.3 \mathrm{U} / \mathrm{mg}$ proteins, with the highest record being $0.54 \mathrm{U} / \mathrm{mg}$ proteins. Lepidopteran (except for Diaphania nigropunctalis) activities against CMC in the gut fluids were noticeably lower than in those in Coleoptera or Orthoptera, at only about 0.05 U/mg proteins. In Diptera (Nephrotoma sinensis and Eristalomyia tenax), Hymenoptera (Arge pagana), and Dermaptera (Labidura japonica) insects, CMC cellulolytic activities in the gut fluid were lower than $0.1 \mathrm{U} / \mathrm{mg}$ proteins.

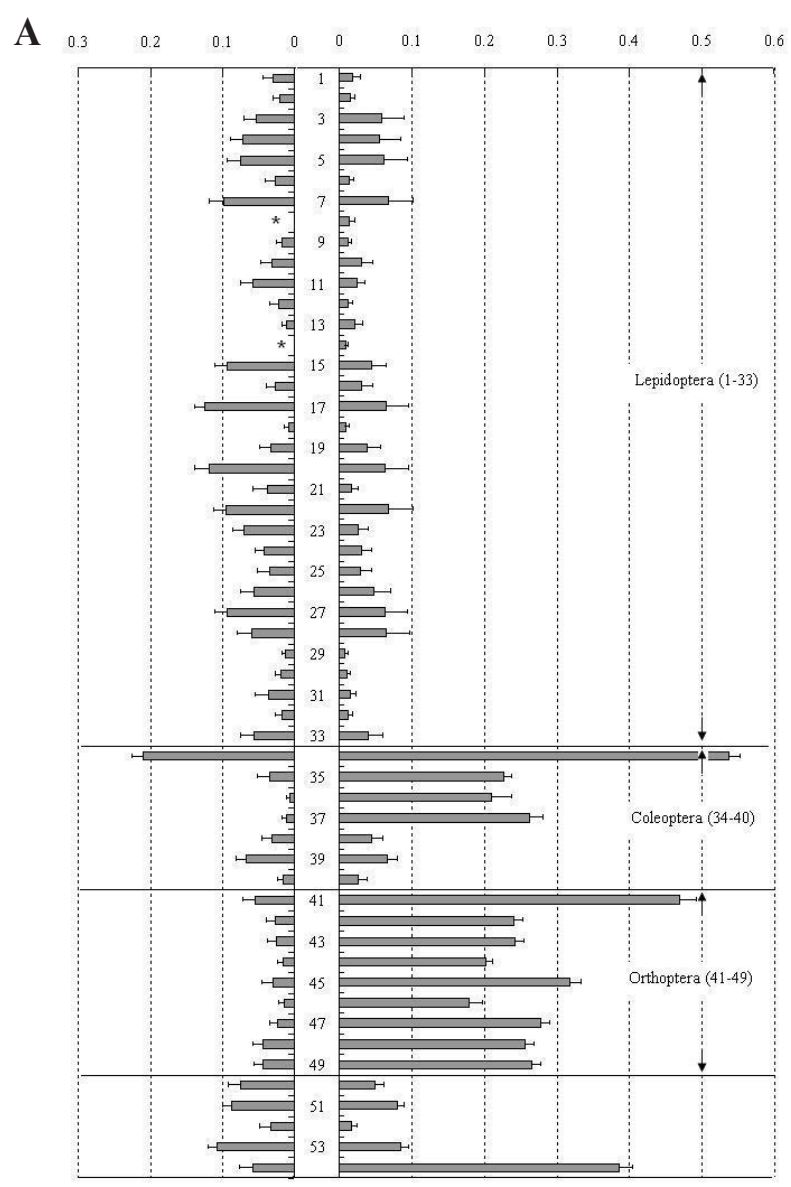

B

Figure 1. Average specific cellulolytic activities (U/mg protein) of gut fluids using (A) FP and (B) CMC as substrates. Numbers in the Figure correspond to Table 1. Asterisks denote missing data due to low sample size. 


\section{FPase in gut fluids}

FPase activities were found in all species tested. The species with the highest gut fluid FPase activities belonged to the Coleoptera (Megopis sinica, $0.21 \mathrm{U} / \mathrm{mg}$ proteins) and Lepidoptera (Ophthalmitis irrorataria, $0.125 \mathrm{U} / \mathrm{mg}$ proteins) (Figure 1A) orders. Orthoptera demonstrated high activity against CMC, but comparatively lower activity against FP.

\section{Detection of cellulases by zymography}

To further elucidate cellulases in diverse insect species, gut digestive fluid samples were analyzed using the zymography method, with CMC as the substrate (Figure 2). The zymography results indicated that the presence of cellulases was order-dependent (Figure 2A and B show Lepidoptera, Coleoptera, Orthoptera, and the other orders). Fewer activity bands were detected in Lepidoptera, with no more than 3 activity bands of different molecular weights spanning 70,44, 35, 27, 23, and $17 \mathrm{kDa}$. In contrast, up to 6 activity bands were detected in Coleoptera, with molecular weights spanning $105,70,45,27,23$, and $17 \mathrm{kDa}$. Up to 5 activity bands were detected in Orthoptera, with molecular weights spanning 105, 83, 70, 45, 35, 27, 20 , and $17 \mathrm{kDa}$. However, no activity bands were detected in the other samples (i.e., Culcula panterinaria, Phyllosphingia dissimilis, Smerinthus planus, and A. pagana).
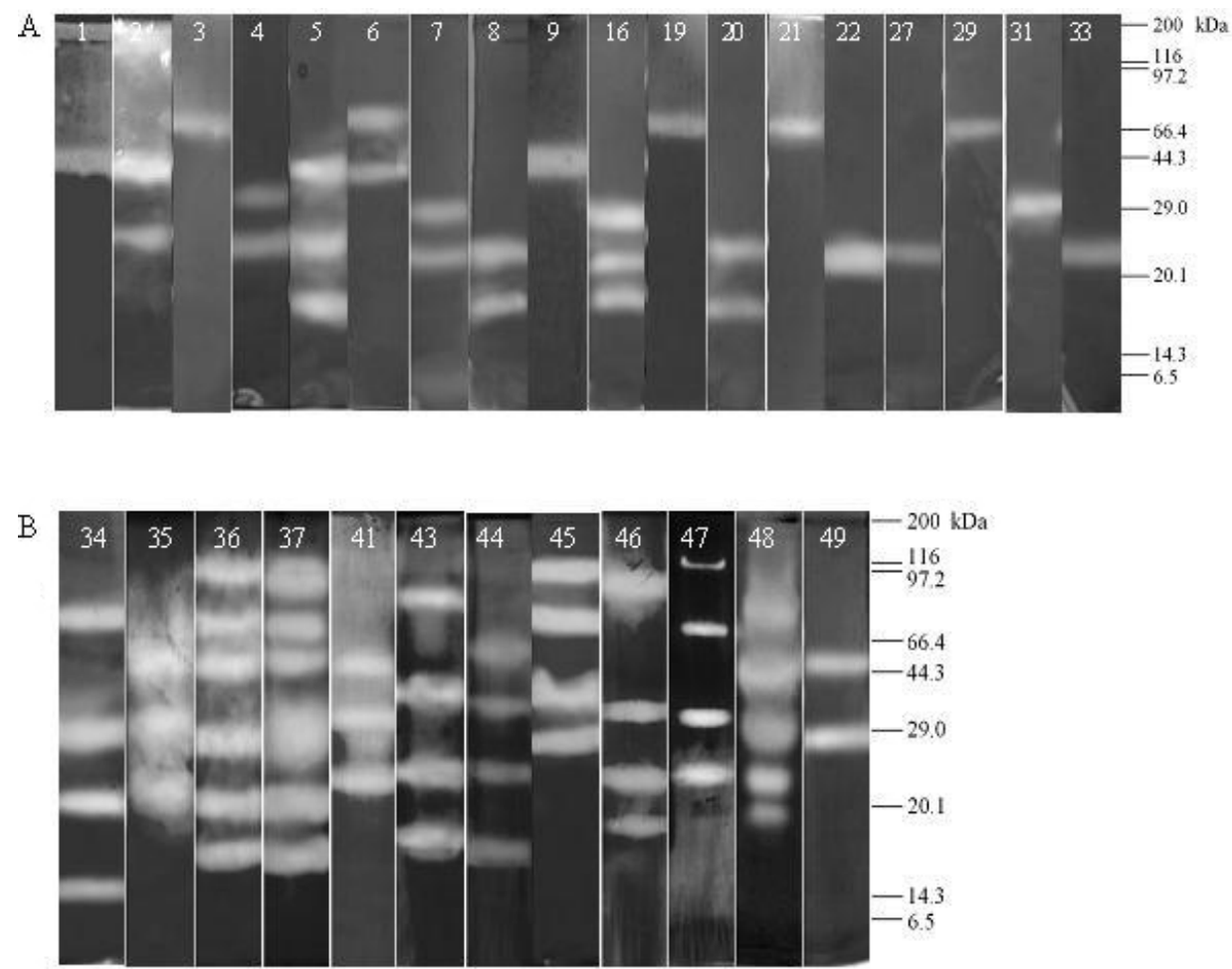

Figure 2. Detection by zymography of cellulolytic protein bands in gut fluids from diverse insect species. A. Lepidoptera (lanes 1-33); B. Coleoptera (lanes 34-37), Orthoptera (lanes 41-49). Numbers in the Figure correspond to Table 1. 


\section{DISCUSSION}

Traditionally, CMC has been used to test for cellulase activity because of its high water solubility, and it could be used as a marker for EG activity. However, CMC does not replicate characteristics of native cellulose. Therefore, FP has been widely used as a cellulosic material that exhibits medium polymerization and crystallinity, from which the synergy of a variety of cellulolytic enzyme components may be detected (EG, $\mathrm{CBH}$, and $\beta$-glucosidases). In the present study, the 2 differently structured substrates were used to quantitatively determine and compare enzymatic activity in the gut fluid samples of 54 insect species that belong to 7 different taxonomic orders. The results showed that the pattern of cellulolytic activity was order-dependent, which indicates that there is a phylogenetic relationship for cellulolytic enzymes (Yokoe and Yasumasu, 1964; Watanabe and Tokuda, 2001). The soluble and noncrystalline CMC was more easily degraded than FP. This difference may be explained by gut fluid activities being higher with CMC in most cases than with the FP substrate, except for individual Lepidoptera species. There were no obvious differences between orders when FP was used as the substrate, except that higher activities were found in several species of Coleoptera and Lepidoptera, which might require further study.

CMC cellulolytic activities were noticeably lower in Lepidopteran gut fluids (generally lower than $0.06 \mathrm{U} / \mathrm{mg}$ proteins) than in the gut fluids of other orders, expect for $D$. nigropunctalis. These results were consistent with those of previous studies (Nakonieczny et al., 2006; Oppert et al., 2010), in which the CMC activity of 24 Lepidopterans was detected at about $0.05 \mathrm{U} / \mathrm{mg}$ proteins. However, the corresponding activities of glycolytic enzymes were higher than those of cellulase from the midgut tissue and liquid gut contents of Apollo butterfly larvae. This difference indicates that alpha-amylase, not cellulase, played the main role in carbohydrate utilization (Nakonieczny et al., 2006). In the present study, the zymography results of cellulose showed fewer activity bands, only 1 to 3 , in Lepidoptera insects. This outcome indicates that Lepidopterans might primarily use starch and other carbohydrate compounds, rather than lignocellulose, as energy sources.

CMC cellulolytic activities were comparatively higher in Coleoptera than in Lepidoptera gut fluids, showing that cellulolytic activities are species-dependent. For example, the CMC activities of Cerambycidae were noticeably higher than those of the other orders. Different feeding habits possibly explain the observed differences in CMC cellulolytic activities. The highest cellulolytic activity was recorded in the Salicaceae $M$. sinica (Cerambycidae) larvae $(0.53 \mathrm{U} / \mathrm{mg}$ protein/CMC, $0.21 \mathrm{U} / \mathrm{mg}$ protein/FPA). In contrast, the lowest CMC activity was recorded for L. serricorne larvae (Anobiidae), which feed on tobacco leaves and cereals as energy sources $(0.03 \mathrm{U} / \mathrm{mg}$ protein/CMC, $0.02 \mathrm{U} / \mathrm{mg}$ protein/FPA). Previous studies have shown that CMC activities in Cerambycidae exceed $0.2 \mathrm{U} / \mathrm{mg}$ protein/CMC (Wei et al., 2006; Geib et al., 2009; Oppert et al., 2010). Wang and Chen (2008) reported high CMC cellulolytic activities in 3 lignocellulose-feeding bark beetle species (Scolytidae); this is consistent with the results of cellulolytic activity analysis in the current study, in which up to 6 activity bands were detected for Coleoptera.

CMC activity in Orthoptera insects has received limited attention. Until recently, previous studies have shown the presence of relatively higher activity against cellulase substrates in Orthoptera insects than in other insect groups (Oppert et al., 2010; Willis et al., 2010). Our experiment also confirmed these results, whereby gut fluid samples from Orthoptera (Acrida cinerea, Fruhstorferiola viridifemorata, and Oxyai hyla intricata) displayed higher activity 
against $\mathrm{CMC}$ (most exceeding $0.20 \mathrm{U} / \mathrm{mg}$ protein/CMC). Furthermore, up to 5 activity bands were detected for Orthoptera by using cellulase zymography. Orthoptera insects may have higher cellulase activity because of their feeding habits. Orthoptera mainly feed on Poaceae, especially hay, which has low levels of starch and other carbohydrate compounds but higher quantities of lignocellulose.

To characterize the cellulolytic activity of insects, we analyzed cellulolytic activity and evaluated zymograms of the gut fluids of 54 insect species that belong to 7 different taxonomic orders. For most insects, gut fluid CMC activities were higher than FP activities. The cellulolytic activities were consistent with the cellulase zymography band, that is, the more activity bands an insect species had, the higher the cellulolytic activity. Higher CMC activities and more zymography bands were found in the insect gut fluids of Coleoptera (Cerambycidae), Orthoptera, and Blattaria (P. plancyi Bolivar) orders than in Lepidoptera. The difference in cellulolytic and $\mathrm{CMC}$ activities may be attributable to different feeding habits, whereby the former species may feed on lignocelluloses and the latter species may feed on starch and other carbohydrate compounds as energy sources.

Traditionally, Orthopteran species have not been the focus of cellulolytic prospecting, probably because there is much debate about the cellulolytic capacity of these insects (Davis, 1963; Evans and Payne, 1964; Clissold et al., 2004). Yet, the cellulolytic activity assays performed in the current study by using the gut fluids from Orthopteran insects revealed levels of activity similar to those of termite and beetle species. Therefore, further studies are required to determine the specific origin of enzyme activities detected for Orthopteran insect species in the present study. Ultimately, the purification, cloning, and characterization of novel cellulolytic enzymes obtained from these insect species might provide invaluable foundation for efficient and low-cost lignocellulose degradation and ethanol biofuel production.

\section{ACKNOWLEDGMENTS}

Research supported by the Project of National Science Foundation of China (\#31170350).

\section{REFERENCES}

Cazemier AE, Op den Camp HJM, Hackstein JHP and Vogels GD (1997). Fibre digestion in arthropods. Comp. Biochem. Physiol. 118: 101-109.

Clissold FJ, Sanson GD and Read J (2004). Indigestibility of plant cell wall by the Australian plague locust, Chortoicetes terminifera. Entomol. Exp. Appl. 112: 159-168.

Davis GRF (1963). Carbohydrase activity of alimentary canal homogenates of five grasshopper species (Orthoptera: Acrididae). Arch. Int. Physiol. Biochim. 71: 166-174.

Evans WAL and Payne DW (1964). Carbohydrases of the alimentary tract of the desert locust, Schistocerca gregaria Forsk. J. Insect Physiol. 10: 657-674.

Geib SM, Jimenez-Gasco MM, Carlson JE, Tien M, et al. (2009). Effect of host tree species on cellulase activity and bacterial community composition in the gut of larval Asian longhorned beetle. Environ. Entomol. 38: 686-699.

Geib SM, Tien M and Hoover K (2010). Identification of proteins involved in lignocellulose degradation using in gel zymogram analysis combined with mass spectroscopy-based peptide analysis of gut proteins from larval Asian longhorned beetles, Anoplophora glabripennis. Insect Sci. 17: 253-264.

Gijzen HJ, van der Drift C, Barugahare M and Op den Camp HJ (1994). Effect of host diet and hindgut microbial composition on cellulolytic activity in the hindgut of the American cockroach, Periplaneta americana. Appl. Environ. Microbiol. 60: 1822-1826.

Jing SN, Yin YP and Wang ZK (1996). Studies on the cellulases resource in some species of Longicorn borers 
(Coleoptera:Cerambycidae). Sci. Silvae Sin. 32: 441-446.

Lo N, Watanabe H and Sugimura M (2003). Evidence for the presence of a cellulase gene in the last common ancestor of bilaterian animals. Proc. Biol. Sci. 270 (Suppl 1): S69-S72.

Miller GL (1959). Use of dinitrosalicylic acid reagent for determination of reducing sugar. Anal Chem. 31: 426-428.

Nakonieczny M, Michalczyk K and Kedziorski A (2006). Midgut glycosidases activities in monophagous larvae of Apollo butterfly, Parnassius apollo ssp. frankenbergeri. C. R. Biol. 329: 765-774.

Oppert C, Klingeman WE, Willis JD, Oppert B, et al. (2010). Prospecting for cellulolytic activity in insect digestive fluids. Comp. Biochem. Physiol. B Biochem. Mol. Biol. 155: 145-154.

Picart P, Diaz P and Pastor FI (2007). Cellulases from two Penicillium sp. strains isolated from subtropical forest soil: production and characterization. Lett. Appl. Microbiol. 45: 108-113.

Sun JZ and Scharf ME (2010). Exploring and integrating cellulolytic systems of insects to advance biofuel technology. Insect Sci. 17: 163-165.

Wang JM, Chen XM, Feng Y and Duan ZY (2007). Comparison of components and activity of digestive enzymes between two xylophagous insects. Forest Res. 20: 170-175.

Wang SJ and Chen H (2008). Digestion enzymes of three bark beetle species (Coleoptera: Scolytidae) in the Qingling Mountains. J. Northwest A\& F Univ. (Nat. Sci. Ed.). 36: 142-148.

Watanabe H and Tokuda G (2001). Animal cellulases. Cell Mol. Life Sci. 58: 1167-1178.

Wei YD, Lee KS, Gui ZZ, Yoon HJ, et al. (2006). Molecular cloning, expression, and enzymatic activity of a novel endogenous cellulase from the mulberry longicorn beetle, Apriona germari. Comp. Biochem. Physiol. B Biochem. Mol. Biol. 145: 220-229.

Willis JD, Klingeman WE, Oppert C, Oppert B, et al. (2010). Characterization of cellulolytic activity from digestive fluids of Dissosteira carolina (Orthoptera: Acrididae). Comp. Biochem. Physiol. B Biochem. Mol. Biol. 157: 267-272.

Wyman CE (1999). Biomass ethanol: technical progress, opportunities, and commercial challenges. Annu. Rev. Energy Environ. 24: 189-226.

Wyman CE (2007). What is (and is not) vital to advancing cellulosic ethanol. Trends Biotechnol. 25: 153-157.

Yokoe Y and Yasumasu I (1964). The distribution of cellulase in invertebrates. Comp. Biochem. Physiol. 13: 323-338.

Yong HL, Yang GJ, Yu YZ and Wang XP (2007). Studies of characters of cellulase in Eucryptorrhynchus chinenis (Olivier). J. Agric. Sci. 28: 16-19. 